NEWS

\title{
African science drops down G8 agenda
}

Researchers lament poor progress on commitments to developing nations.

In the run-up to the G8 summit meeting in Italy from 8-10 July, African science leaders are counting the cost of unfulfilled commitments to their continent made at previous G8 meetings.

At the 2005 Gleneagles Summit in the United Kingdom, the rich G8 nations endorsed many of the proposals put forward by the Commission for Africa, launched by former British prime minister Tony Blair in 2004. These included creating centres of excellence in science and technology across the continent, and setting up African institutes of technology.

"To my knowledge, no new centres of excellence have been set up," says Mohamed Hassan, executive director of the Academy of Sciences for the Developing World (TWAS) in Trieste, Italy, and president of the African Academy of Sciences. "It's very disappointing."

The agenda of this year's G8 summit, which is being held in the earthquake-ravaged town of L'Aquila, renews the focus on Africa, with goals such as tackling the effects of climate change and safeguarding biodiversity on the continent. Yet support for African science is unlikely to be a priority for discussion, says Hassan.

At a G8 satellite meeting on science and international development, organized by TWAS and the Italian foreign ministry and held on 26 June in Trieste, the focus was firmly on Afghanistan. The delegates agreed that international science academies should work with Afghanistan's science ministry to establish a development plan for the coming decade. But African science was not discussed, says Hassan: "I don't think it will be on the G8 agenda."

Myles Wickstead, head of the Commission for Africa

\section{"What has happened} to the concept of African institutes of science and technology?" secretariat until late 2005, also has low expectations for the forthcoming G8 meeting, not least because the Italian government cancelled a meeting of the G8 science and technology ministers that was due to take place on 25 June (see Nature 459, 1041;2009). "There is very little we can expect for science and technology at the Italian summit," Wickstead says.

The United Kingdom's former chief science adviser, David King, who was involved in drawing up the Commission for Africa proposals and is now director of the Smith School of Enterprise and the Environment in Oxford, UK, says that continued pressure needs to be placed on the G8 nations to deliver on their promises. "Questions need to be asked about the priorities set out in Gleneagles," he told Nature. "What has

\section{Red tape}

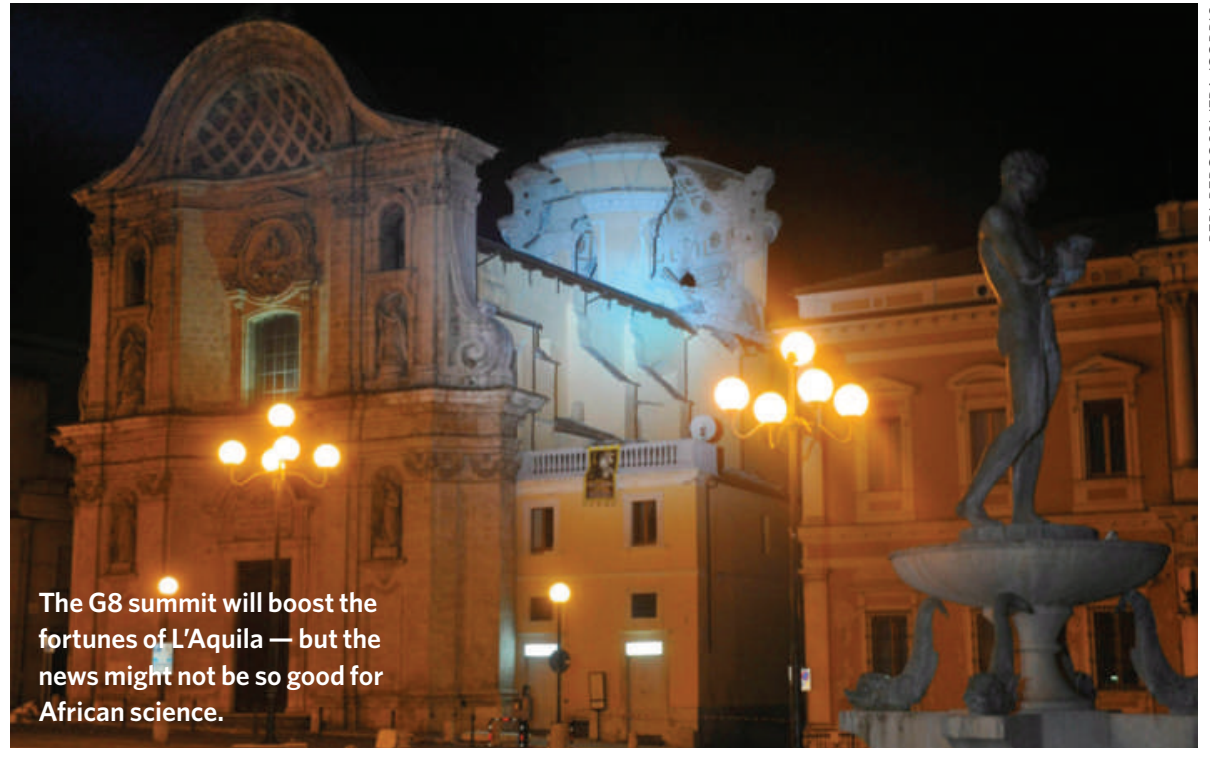

happened to the concept of African institutes of science and technology?"

A key stumbling block has been the G8's failure to commit to donating US $\$ 3$ billion over 10 years to set up the centres and $\$ 500$ million a year over 10 years to strengthen universities, as recommended by the Commission for Africa in 2005. But Hassan says that some of the blame must rest with the African nations. With the exception of South Africa and possibly Rwanda, African nations will not reach the target agreed in 2003 by the African Union, a confederation of 53 African states, of investing $1 \%$ of their gross domestic product in science by 2010 , he says. "African governments have to put their house in order first. If they show progress in investing in science and technology, this will encourage donors."

Tensions over who should be responsible for African science-and-technology aid have certainly hampered progress, says Wickstead. Despite high-level discussions in December last year between the two key players - the African Union and its implementing partner, the New Partnership for Africa's Development (NEPAD) - a single fund for African science still does not exist, he says (see Nature 457, 14; 2009). "Africa has not yet developed a comprehensive plan for science that the donor community can get behind and support," he says.
Despite this, bioscientists in Africa have benefited from four networks set up by the NEPAD and the African Union since 2003, aided by a Can\$30-million (US\$26-million) grant from the Canadian government. Diran Makinde, director of the West African Biosciences Network, says that Spain has contributed $€ 3$ million (US $\$ 4.2$ million) and Finland $€ 400,000$ to bioscience initiatives in Africa. But he adds that the contribution from G8 nations has been small in comparison to what was promised, and that the networks could face tough times if they are not able to secure longer-term funding.

Calestous Juma, a Kenyan professor of international development at the John F. Kennedy School of Government in Cambridge, Massachusetts, says that a better forum is now needed for discussions about harnessing science for African development. If the momentum generated by Tony Blair before Gleneagles bore little fruit, he says, it is unlikely that a less-engaged Italian leadership will be able to achieve much.

Although progress on the G8 commitments to science has been slow, other forums are moving forwards. The European Union, for example, launched a science partnership with the African Union in October 2008. Several initiatives are being funded through the partnership, including grants for Africa researchers that total $€ 36$ million over 3 years - with the first call for proposals to be launched at the end of 2009 . Natasha Gilbert

See 'African institutions gain support networks', page 23. 